\title{
The Influence of Edgar Allan Poe's Life Experience on His Writings
}

\author{
From the Psychoanalytic Perspective
}

\author{
Ke Xiong \\ Sichuan Changjiang Vocational College \\ Chengdu, China
}

\begin{abstract}
Psychoanalytic literary criticism is the literary criticism that is influenced by the tradition of psychoanalysis begun by Sigmund Freud. It is a literary approach where critics see the text as if it were the reflection of writer's repressed desire. It uncovers the author's hidden motivations. Edgar Allan Poe is one of the most controversial writers in the 19th century in America. His short stories reflect his repressed desire which was caused by his tragic and unfortunate life. This paper aims to study the influence of Edgar Allan Poe's life experience on his writings and try to explain why the characters in his short stories are always dead or mad.
\end{abstract}

Keywords-psychoanalytic criticism; Poe's life experiences; libido; repressed desire; abnormal psychology

\section{INTRODUCTION}

Unlike many other schools of criticism, psychoanalytic theory with its accompanying practical applications is unique. A psychoanalytic approach can reveal intriguing details about the author and the reader, elements of the interpretative process. Psychoanalytic theory finds its roots in psychoanalysis developed by Sigmund Freud. He argues that the literary works is the repressed desire of the author. He sees the motive of literature writing is the sexual drive. The artists are like common people. When his sexual desire cannot be satisfied, he would try to express their feelings by writing. Then he can give vent to his emotion. Edgar Allan Poe is an American poet, short story writer, editor, critic and one of the leaders of the American Romantics. His childhood and his life experience are miserable and unfortunate. Poe had a miserable childhood. He lost many of his closest loved ones to death, which affected his mind. He became focused on death and its effects on those left behind. His obsession with death and loss can be seen in most of his writings. He was frustrated in love experience. The object of psychoanalytic literary criticism, at its very simplest, can be the psychoanalysis of the author or of a particularly interesting character. This paper tries to study the influence of Poe's life experience on his literary writings.

\section{FREUD'S PSYCHOANALYTIC LITERARY CRITICISM}

Psychoanalytic literary criticism refers to literary criticism which, in method, concept, theory, or form, is influenced by the tradition of psychoanalysis begun by
Sigmund Freud. It is a literary approach where critics see the text a kind of dream. This means that the text represses its real content behind manifest content. The process of changing from latent to manifest content is known as the dream work, and involves operations of concentration and displacement. The critic analyzes the language and symbolism of a text to reverse the process of the dream work and arrive at the underlying latent thoughts. Freud based his psychoanalytic theories on his tripartite model of the human mind: the id, the ego, and the superego. According to Freud, id is unconscious and is composed of sexual desire and aggression. It is dominated by the "pleasure principle". Freud said:" Our whole mental activity appears to be resolved to the pursuit of happiness and avoid suffering, and it is by automatically adjusted by the pleasure principle" (Freud, S.1949).It is lawless and amoral, serving to gratify the dark desires. Ego represents the rationality, which satisfy the instinctive demand. It is dominated by the "Reality principle". Superego is represents the social ethics. It is the opposite side of the id, working to repress the instinct impulse. It is dominated by "morality principle", which will result in an unconscious and often overwhelming sense of guilt. Libido is the main component of id. This is the basic instinct of human beings and drives them to pursue happiness especially sexual pleasure.

In literature creation and literary criticism, Freud holds this pan-sexualism. He sees sexual desire the motive of literary writing. The artists and writers are like common people. When their sexual desire are repressed and not satisfied, they will express their feelings through literature writing. So their creative motives are "sexual desires". Freud believed that art and literature is the "Sublimation" of sexual instinct. By this sublimation, the repressed Libido can be expressed through the way which can be accepted by the public.

\section{THE INFLUENCE OF POE'S LIFE EXPERIENCE ON HIS WRITINGS}

\section{A. Poe's Miserable Life Experience and His Frustration in His Love Affairs}

Poe was born in Boston in 1809 in a street artist family. His parents did not have a good relationship. So his mother 
took Poe away and left home. In 1811 his mother died because of bad disease. A business man John Allan adopted him and was caring for him. Poe had a happy childhood and he could go to school like other children. In Poe's middle school time, he fell in love with the mother of a friend. But she died before long. Then Poe wrote "To Helen". The next year, Poe's father inherited a rich heritage, but both parents are strongly opposed, and finally the abolition of marriage by girl's parents. At the age of 17 , Poe went into the University of Virginia. He did not stay in the university for one year, and then returned to Richmond, when he found the previous lover find lover Sarah Elmira Royster married another man, Poe was deeply hurt. When he is 20 years old he fell in love with his cousin Elizabeth, for whom he also wrote many poets. Poe's mother died, when he was 3 years old. From then on, his frustration began: at the age of 15 "the first pure and good woman," friend's mother died; at the age of 20, his foster mother died. By the age of 23, Poe was abandoned by another 3 woman. "As the three lovers left him, he would feel that they were dead" (Albert Modal, 2006)

Try to imagine how you would feel if every family member you truly loved died. Edgar Allen Poe didn't need to imagine this situation; he lived it. Poe had a miserable childhood. He lost many of his closest loved ones to death, which affected his mind. He became focused on death and its effects on those left behind. His obsession with death and loss can be seen in most of his writings. This experience showed that, the frustration of love affairs made Poe write those Gothic stories that most women characters are dead or mad. By applying Freud's psychoanalytic principles to Poe's life and his canon, Marie Bonaparte believes that Poe was attached to his adopted mother and her death left him a void in his libido. Through his marriage to his cousin and his avoiding the sexual consummation of the marriage, Poe preserved his sexuality. That is to say, Poe's love frustration and his abstinence forced the powerful urges of his libido back into his unconscious. Poe's libido is suffocated by his love experience. (Bonaparte, 1949)

Thus the characters in Poe's stories are always dead, especially those beautiful women. He believes that death of woman is a kind beauty. This may reflect his unconscious death feelings. In nearly every one of his tales, one of the characters has died or is being mourned and this sets the dark tone in Poe's works. The death in Poe's works is full of the beauty of sorrow, terror and romance. He believes that the death of beautiful women is the extreme beauty. His love of death has great relations with his life experiences. His description about death also exposes his pursuit of beauty in his frustrating life.

Poe's short and difficult life experiences leads to his death complex. Exploring "Beauty of Death," he described the death natural and wonderful. For a person whose life is full of frustrations and pain, taking satisfactory pursuit of "Beauty of Death" as his composition concept to achieve his dreams through death is very natural. Facing to the death, Poe shows the general thinking of a philosopher. Experience of his life makes him realized that the death is a "good thing". "Death is a kind of beauty, a kind of extraordinary beauty (Yong YI, Xiao Hua, 1998)." Poe understands "Beauty of
Death" when in the face of grief and terror experience Although his works are full of despair, pain, sorrow and terror, it also implies precisely that the depths of his heart are filled with pursuit of desire, and a yearning for the warmth and love. (Jiang Shui'e, 2008)

Poe's female characters often meet an untimely death. In Ligeia, Ligeia dies, not just to keep her youth and beauty, but because her husband fears that she has intelligence. The love of the narrator's wife has passed away and he must try to get through his life without her. Although she is dead, her double resurfaces at the end of the surface and the process of decay has obviously been halted by some supernatural means. With this twist in the end, death remains a shadow looming throughout the entire story. Ligeia is much like Poe's dead adopted mother, Mrs. Allan, who is extremely intelligent, "such as I have never known in a woman." Most importantly, she served as the narrator's teacher in "metaphysical investigation", passing on "wisdom too divinely precious not to be forbidden!" (Poe, 1850)

Another typical work that reflects his libido is The City in the Sea. It is one of Edgar Allan Poe's short poems, and is well known for its dreamy tone and horrible atmosphere. In this poem, Poe portrait a dark image of an ancient Gothic city that is abandoned and desolate. Poe describes the solemn city with its magnificent buildings and monuments as the remnants of a seething metropolis. This text reveals explicit sexual imagery, signifying the emergence of Poe's repressed libido. Poe's repressed libido is reflected from this poem. He did not gain woman's love, then he dreamed it want it in his writings.

According to psychoanalysis, the abnormal fear is the repressed sexual desire this is the boycott to "libido". A person's sexual impulses cannot be suppressed, if it is not shown in other ways. Poe suffered "libido" all his life, he is exactly Roderick Usher in Fall of the House of Usher.

Roderick Usher was eccentric and depressed. He attributed the cause of his disease to his sister, Madeleine. Her illness made him worried. In fact, the cause of his illness is in his unconsciousness. If we are familiar with psychoanalysis and Poe's life experience we know that Poe and Roderick have the same life experiences. He lost his mother, and later lost a friend's mother, and later lost his adopted mother. There is no doubt that Roderick and Poe lost in love three times. Similarly, he always lived in fear, and always felt that he would soon die .He was afraid of the future and read some fanciful books, or thought of some ridiculous things. His sister died, he even let "I" to help him to bury her. He then fell into fantasy, that his sister was buried alive He therefore extremely scared, worried that she would retaliate. Therefore, when "I" read to him a legendary story, he associated the story of him and his sister Madeleine together. He said he heard the crack of her coffin, and the chains of coffin the also rattled. He seemed to think that she crawled out from the cellar, and then grabbed him tightly, hardly pinching his neck. In this way, he died in fear. Obviously, this is the imagination of, because it was impossible for Miss Madeleine to nail from the coffin and escape. Roderick died of his own abnormal fear. 


\section{B. The Influence of Miserable Life and Abnormal Physic on His Writings}

Poe whole life was poor and his writing ability was not recognized by the society and his beloved women. So he hated the society and the people who despite him and contempt him. But he cannot be achieved punishing them in the reality, so he in punished them in the literature. This is what Freud said that all the writers have psychosis. Living a life of misery, enduring his parents' death at an early age, numerous love affairs shattered and torn, and maintaining no substantial income, Edgar Allan Poe committed his life to writing. While everyone else was not paying him much attention, Poe continued to write new, provocative and different pieces than what the public and literary elite was used to.

He used exaggerate way to show a pathological psychology. He wrote so many revenge stories to show his resentful feelings towards the society. He liked to write critical articles, and to use harsh words to make some writers feel the pain. He wanted to punish literary rivals, and in the article he deliberately let out his hatred for them. He had an unconscious to create pain. In The Black Cat, he has a black cat pet. Although their original relationship is one of respect and love, the situation soon changes. The narrator becomes somewhat possessed with the hate for the cat. He turns against his wife and stabs his cat in the eye. By the end of the story, he killed his wife in an attempt to kill the cat. Afterwards, the narrator does not even feel remorse for the wrongful death of his wife. Instead, he is just happy that the cat disappeared. The whole story is bloody and disgusting, but Poe described it as if the story has nothing to do with him. This unconscious hate to the society and unfair feeling is the original writing motivation.

Revenge always accompanies the death. In The Masque of the Red Death, no man or woman can escape death. The tone in The Masque of the Red Death is bleak and dreary. Death itself made an appearance at this ball, both as a physical character and as the end to life. At midnight a stranger "shrouded from head to foot in the habiliments of the grave (Poe, "Masque" 389)" appeared, resembling the Red Death itself. This figure led the prince and his people to the dreaded black chamber, that with its "blood-tinted panes, was ghastly in the extreme (Poe, "Masque"387)". Here the Red Death finally claimed its victims, and the court perished from the same fate as the commoners. This seems to be an act of revenge as well as death. The prince and his court had abandoned the commoners to protect themselves. The ebony clock seems symbolic of time, as well as a reminder of the outside world. They are reminded that while they spend their time in leisure, many others are dying.

Another great element in all of Poe's stories, what could be called his "signature", is the certainty that there will always be a gruesome horror-filled ending. This may be the Poe's wish that all those people who rejects him and those who he hated. A terrifying occurrence will always happen. Although Poe's stories are short stories, he always takes the time to let the reader get acquainted with the narrator, and then uses the reader's trusting familiarity with the narrator to make the endings scary and surprising. He shares the "madness" that the narrator feels, but still gives the conclusion such a twist that the reader can't help but be shocked. In The Cask of Amontillado, the reader knows that the narrator harbors a hatred of Fortunato, but when the narrator bricks him into the wall of the catacombs, the reader still feels horror and shock. This is what he cannot do in the real life, so he punished those "enemies" in his works.

Hop-Frog is also the revenge writing. In Hop-Frog, HopFrog is planning something, in the end; he sets the kings and his attendants aflame. He gave gruesome-filled surprise to the readers from the disgusting murder and from Hop-Frog's obvious pride and lack of remorse in his words in the last scene: "I now see distinctly...They are a great king and his seven privy councilors...I am simply Hop-Frog, the jesterand this is my last jest." We can guess that Hop-Frog is Poe himself. He thought he was talented but was not recognized by the society. He was full of resentment. He is ill-fated and can only write to retaliate against all the forces of injustice.

\section{CONCLUSION}

Edgar Allan Poe is one of the most controversial writers in the $19^{\text {th }}$ century in America. His short stories reflect his repressed desire which was caused by his tragic and unfortunate life. Edgar Allan Poe had a miserable childhood. He lost many of his closest loved ones to death, which affected his mind. He became focused on death and its effects on those left behind. He believed he has an extraordinary talent. But he was always contempt by others. His brilliance was not realized and accepted by the mainstream at that time. Only after he died, he was accepted by the outside world and his writings and creations were welcomed by the society. Many people then began to study his works. Psychoanalytic literary criticism is the literary criticism that is influenced by the tradition of psychoanalysis begun by Sigmund Freud. It is a literary approach where critics see the text as if it were the reflection of writer's repressed desire. It uncovers the author's hidden motivations. It is the reflection of writer's resentful feelings and his unconsciousness. This paper analyzes the relationship between Poe's life and his literary works. It shows that the death and madness of the hero's fate is the portrayal of the author.

\section{REFERENCES}

[1] (Freud, S.1949). An Outline of Psychoanalysis. New York: Norton.

[2] M.Bonaparte.J.Rodker (trans.). London: Imago Publishing Co., Ltd., 1949.

[3] Poe, Allan Edgar. "Ligeia" (G), The Works of the Late Edgar Allan Poe, 1850 .

[4] "The Philosophy of Composition" (1846). (A), Graham's Magazine, Vol. XXVIII, No. 4, April, 1846.

[5] "Ligeia" (G), The Works of the Late Edgar Allan Poe, 1850, 1:453468.

[6] "The Masque of the Red Death" (Text 04), Broadway Journal, July $19,1845$.

[7] Weekes, Karen. "Poe's feminine ideal", collected in The Cambridge Companion to Edgar Allan Poe, edited by Kevin J. Hayes. Cambridge University Press, 2002. p. 152. ISBN 0521797276. 
[8] Albert Modal, liu Wenrong (translator). Porn motivation in literature [M]. Shanghai: Wenhui press, 2006.

[9] Jiang Shui'e. On the beauty of death in the creation of Allan POE, Journal of Huaihua College [J], 2008, (3).

[10] Yong Yi, Xiao Hua. "Death Theory" [M] Guangzhou: Guangzhou Culture Press, 1998 